\title{
Flourishing Together: Co-Learning as Leaders of a Multicultural South African Educational Research Community
}

\author{
Kathleen Pithouse-Morgan \\ University of KwaZulu-Natal \\ South Africa \\ Theresa Chisanga \\ Walter Sisulu University \\ South Africa \\ Thenjiwe Meyiwa \\ University of South Africa \\ South Africa \\ Delysia Norelle Timm \\ Durban University of Technology \\ South Africa
}

\begin{abstract}
In South African public higher education, the miseducative legacies of the past weigh heavily. This article offers our learning as leaders of a multicultural community of university educators that seeks to contribute towards repairing the damages of a divided and discriminatory past by means of self-study research. Through a collaborative arts-informed analysis process, we have heard multiple perspectives from community participants and expressed our own learning in dialogue with theirs. This has enabled us to recognize shared qualities of caring, listening, and creativity as vital to a socially just reimagining of higher education communities.
\end{abstract}

KEYWORDS: arts-informed research, collaborative research, creative analysis, self-study research, South Africa

Situating Ourselves in a Complex Higher Education Context

The Outgrowth of the Transformative Education/al Studies (TES) Project

Placing Co-learning at the Heart of the Community

Retracing our Collective Arts-Informed Analysis Process

Flourishing Together Through Caring, Listening, and Creativity

Notes

Acknowledgment

References

Author Contact

In this article, we focus on our co-learning as leaders of the Transformative Education/al Studies (TES) project in South Africa. We describe a collective artsinformed analysis process in which we sought to encounter multiple perspectives 
of project participants and to articulate our learning in dialogue with theirs. To begin, we offer a brief portrayal of ourselves as project leaders within our complex South African higher education context. Next, we explain the outgrowth of the TES project. Then, we retrace and illustrate our collective arts-informed analysis process. To close, we offer our learning-in-progress as a resource for learning about and with multicultural educational research communities.

\section{Situating Ourselves in a Complex Higher Education Context}

Our multicultural leadership team of four Southern African women brings together diverse cultural heritages, ethnicities, histories, languages, nationalities, and perspectives. Theresa, for example, was born and grew up in a rural environment in Zambia, before entering university in that country and being introduced to everything "modern" for lack of a better term. Doing graduate studies and working abroad has meant that she had to transition between cultures and constantly do cultural-code-switching (Molinsky, 2007). Delysia describes herself as multicultural as she is biracial, drawing from Black/African and White cultures in South Africa. Thenjiwe is an African Black woman who defines her existence as an explosive conglomeration of many "reserves," which are made up mainly of the Zulu ${ }^{1}$ oral tradition. Her culture is drawn from an unwritten culture of the Inanda Mission Reserve, a peri-urban Christian community in north Durban, one of the main cities in South Africa. She also draws her existence and culture from her great-grandmothers, one of Scottish decent and the other of $\mathrm{Xhosa}^{2}$ origin. Kathleen, who grew up in a sheltered White English-speaking middle-class environment during apartheid, has become more and more conscious of other South Africans' lived experiences of oppression and exclusion. She has spent much of her adult life learning to grapple with her own implication as someone who has been privileged by the reprehensible strategies of the apartheid state.

Furthermore, our team brings together a range of educational backgrounds, qualifications, and academic disciplines. Our research profiles vary from a novice researcher to more experienced researchers. We are also located in three very different universities, set 540 kilometers apart, in two provinces of South Africa. South African universities are classified as comprehensive universities, universities of technology, or research-intensive universities (South African Council on Higher Education, 2007). These distinct kinds of university offer diverse qualifications, student and staff profiles, milieus, amenities, opportunities, and challenges for teaching, learning, and research. The histories and characteristics of these universities reflect multiple academic and institutional cultures, which in themselves have become part of the learning resources for the TES project. The university where Theresa is located, for instance, is an example of an underresourced comprehensive university, situated in an underdeveloped rural area. This university was designated as a "Black" university during apartheid, and it remains one of the most inadequately resourced universities in the country. Consequently, research, learning, and teaching bring numerous challenges for 
staff and students (Meyiwa, Chisanga, Mokhele, Sotshangane, \& Makhanya, 2014). For universities of technology, such as the urban, inner city university where Thenjiwe and Delysia are located, their strength is in teaching and learning, with a low participation rate of staff and students in research activities. This means that these institutions have to deal with the challenge of enhancing their credibility as research institutes, while simultaneously having to obtain the financial means to fund this research (Du Pré, 2010). The particular university of technology where Thenjiwe and Delysia are situated is the result of a post-apartheid merger in 2002 between a traditionally "Indian" institution and a "White" institution, both offering mainly undergraduate degrees and diplomas during the apartheid era. The merged university of technology has only recently started offering postgraduate qualifications to its students who are mainly from underserved or disadvantaged communities. At research-intensive universities, such as the urban, highly research-productive university where Kathleen is located, all university educators are expected to demonstrate strength in both research and teaching, which can produce challenges related to negotiating these competing demands, especially for early career academics (Pithouse-Morgan, Naicker, Pillay, Masinga, \& Hlao, 2016b).

\section{The Outgrowth of the Transformative Education/al Studies (TES) Project}

The repressive and discriminatory apartheid regime (1948-1994) deliberately sought to impoverish education for the majority of South Africans (Nkomo, 1990). Accordingly, soon after the birth of South Africa's democracy a bold vision was set out for a far-reaching transformation of South African public higher education, one in which "all existing practices, institutions and values [would be] viewed anew and rethought in terms of their fitness for the new era" (South African Department of Education, 1997, p. 3). Nevertheless, more than two decades later, higher education in South Africa continues to be constrained by impediments that can be traced back to apartheid strategies and systems. These include poor undergraduate success and "throughputs" (particularly among students from underserved and disadvantaged communities); slow, if any, alteration of outdated curricula; higher education staff lacking in requisite graduate qualifications; an aging professoriate; and too few new and young researchers (Academy of Science of South Africa, 2010; South African Council on Higher Education, 2014; South African National Planning Commission, 2012). Moreover, the higher education landscape is still shadowed by persistent social divisions and distress rooted in lived experiences of unfairness, oppression, and alienation linked to, among other factors, race, gender, ethnicity, religion, sexuality, ability/disability, and nationality (Pithouse-Morgan et al., 2012; Pithouse-Morgan, Pillay, \& Naicker, 2017; Soudien et al., 2008; Timm, 2016). Because past inequalities and injustices have not been seen redressed in substantive ways, heated student protests have been a feature of the post-apartheid public higher education landscape since 1994 (Davids \& Waghid, 2016). In recent years, student 
protest action has gained momentum under the banner of a national "\#FeesMustFall" movement (Davids \& Waghid, 2016).

The TES project was conceived in response to two key aspects of the national post-apartheid policy vision for transformation of higher education (South African Department of Education, 1997): first, "[creating] an enabling institutional environment and culture that is sensitive to and affirms diversity, promotes reconciliation and respect for human life" (p. 7), and second, "the development of a reflective capacity and a willingness to review and renew prevailing ideas, policies and practices based on a commitment to the common good" (p. 4). The founding of the TES project was rooted in values espoused in the recent South African Human Rights Commission report as it relates to the ideal state of transformation at public universities: "A transformed system of higher education is the one that is free from all forms of discrimination (whether direct or indirect) and artificial barriers to access and success, as well as the one that is built on principles of social inclusivity, mutual respect and acceptance" (2016, p. 7).

Since its inception in 2011, the TES project has brought together a multiinstitutional, multicultural, and transdisciplinary community of university educators interested in developing their educational practice in ways that are responsive to vital tenets of higher education transformation. Because the project was responding to critical national higher education priorities, the South African National Research Foundation provided six years of initial funding, which helped the community to establish a firm footing.

\section{Placing Co-learning at the Heart of the Community}

The TES community comprises approximately 40 educators from varied university contexts. Community participants offer multiple ways of knowing, seeing, and doing, inspired by a range of academic and professional disciplines including accounting education, communication studies, educational leadership, English language studies, fashion design, gender studies, jewellery design, mathematics education, teacher development, and theatre and performance studies. Hence, the TES community has come to be characterized by "an appreciation and application of the concept of transdisciplinarity" (Davis, 2017, p. 138). The intention of this transdisciplinarity is not only to draw on heterogeneous bodies of knowledge and "patterns of knowing" (Carper, 1978, p. 13), but also to generate pluralistic ways of knowing and doing through "co-generative dialoguing" (Roth \& Tobin, 2004, p. 2).

TES community participants themselves are diverse in many ways, such as age, gender, language, cultural heritage, ethnicity, and race, as well as in levels of experience in teaching, research, and publication. Such complex diversity is especially pertinent in that although race was the dominant category used to divide and stratify higher education in apartheid South Africa, this intersected with many other taxonomies of exclusion and discrimination, such as gender, ability/disability, national origin, language, and geographical location (South African Department of 
Education, 1997). Hence, our vision of a multicultural higher education community is an expansive one in which a multiplicity of voices and lived human experiences is made visible and embraced as a vital collective learning resource within an enabling, pluralistic environment (Conle, 2004; Pithouse-Morgan et al., 2017; PithouseMorgan \& Samaras, 2018).

Within and across different university contexts, the TES project has aimed to offer crucial support in bringing higher education teaching and research into dialogue through self-study research methodology. Self-study research was originally developed in the early 1990 s by teacher educators who wished to "develop self-understanding personally and professionally by examining their practice with colleagues; and consider how to reframe and improve professional practice" (Pithouse-Morgan, Coia, Taylor, \& Samaras, 2016a, p. 443). Subsequently, self-study has continued to grow and develop in new ways in varied fields and specializations and across wide-ranging educational contexts (PithouseMorgan \& Samaras, 2018).

By adopting self-study as a lens through which to look critically and creatively at personal experience and professional practice, as well as broader social-ethical-political contexts and issues (Mitchell \& Weber, 2005), TES participants seek to contribute to a collective, socially just, reimagining of South African public higher education. Some community participants are university educators who have chosen to undertake graduate studies using self-study methodology, while other community members are research supervisors ${ }^{3}$ who are guiding these "staff-students." A core research question, "How do / transform my educational practice?" is explored in relation to educators' particular contexts as well as across the community, becoming, "How do we transform our educational practice?"

Self-study research requires collaboration with others during the research process (LaBoskey, 2004). Others include peers who, as critical friends, pose questions and offer advice (Schuck \& Russell, 2005). For the TES community, these collaborative ideals have been lived out in the form of TES participants serving as critical friends for each other's research (Harrison, Pithouse-Morgan, Conolly, \& Meyiwa, 2012). Collaboration is at the center of our explorations as critical friends who work together to contribute and ponder multiple perspectives and insights (Schuck \& Russell, 2005).

A range of international studies emphasize how collaborative and social approaches to graduate supervision and academic support can enhance research capacity, productivity, and quality in higher education institutions (see, among others, Loveless et al., 2013; Samaras et al., 2014; Wisker, Robinson, \& Shacham, 2007). The work of the TES community builds on an understanding that "creating an inclusive academic climate is critical to developing scholars [and educators] at all stages of the academic career ladder" (Cariaga-Lo, Dawkins, Enger, Schotter, \& Spence, 2010). The community has offered sustained support for participants who are at different stages of the graduate research process, as well as both novice and experienced self-study researchers, thus facilitating learning and collaboration across varying levels of experience. We meet at least once a year in 
large groups at the inter-institutional level and also monthly or weekly in smaller groups at each of the three host universities. An online social learning site offers a space for ongoing virtual conversations to extend and enhance our meetings. Community workshops and meetings have always been open to any university educators who wish to learn about self-study and to contribute to the collective learning of the group. Invitations to TES project activities have been shared via university-wide notices, online and national research networks, and word of mouth.

Our community's face-to-face and virtual meeting spaces have provided regular opportunities to share work in progress for constructive feedback within an appreciative and supportive environment (Harrison et al., 2012). Working with critical friends in the community has encouraged members to be accountable to themselves and to each other (Samaras, 2011). We have found that we share collective values, which have become visible through a conscious effort to learn from and develop each other's research capacity-doing so within a safe space. We have come to articulate these collective values as reflexive ubuntu (Harrison et al., 2012). Reflexive ubuntu unifies the following: (a) research reflexivity, which mainly constitutes paying critical attention to how researchers' positioning, understandings, and values affect research; (b) Southern African ubuntu philosophy, which is underpinned by the principle of locating oneself in the experiences of others as an ethics of care; and (c) what we term "co-flexivity," which we have described as "being reflexive together through thinking deeply about and questioning our professional practice and selves in dialogue with significant others" (Pithouse-Morgan et al., 2015, p. 148).

An integral part of our mutual learning has been composing and sharing personal history narratives and memory-work writing (Mitchell \& Pithouse-Morgan, 2014; Samaras, Hicks, \& Berger, 2004), as a basis for exploring "those formative, contexualized experiences that have influenced [our] thinking about [education] and [our] own practice" (Samaras, Hicks, \& Berger, 2004, p. 909). In particular, there is appreciation of complexity and plurality that exists within a variety of personal stories of lived experiences, as well as their contexts. In South Africa, "the strategies of the apartheid state...locked doors between people and denied them access to each other's experience" (Haarhoff, 1998, p. 10). Racial classifications were used to disconnect South African people by confining them to separate spaces: educational, geographical, social, and others (Clark \& Worger, 2016). Southern African poet and writer Dorian Haarhoff counselled that when we "re-member (the opposite to dismember) our stories, we [can] reconstruct and reconnect our lives" $(1998$, p. 5). With this in mind, our community is cognizant that all participants' stories have significant value in and of themselves and as portals for reconnecting across historical divides and damages. This is significant for the entire group, as relationships of mutual trust have had to be built to foster the free sharing of stories, experiences, and feelings.

\section{Retracing Our Collective Arts-Informed Analysis Process}


In a research project involving so many people and with a great many varying dynamics, leadership is important. From the time of the establishment of the TES project in 2011, the four of us have been meeting regularly to explore our leadership experiences and practices. As this group, we have been led by Kathleen in principle as chief investigator; she will, for example, organize the logistics of the workshops, but the leadership team as a whole will meet and agree on the process for each workshop and then share with TES participants the responsibility of presentations and guidance of group activities.

As the TES leadership team, we reached a point where we wanted to enhance our learning and that of the community through a collaborative, reflexive analysis of both leaders' and participants' experiences in the project. We asked, "What pedagogic implications for educational research capacity development can be drawn from a collective analysis of TES project experiences?" Responding to this question posed something of a challenge, as we had to consider how we might most fruitfully bring together the diverse community participants in a collective analysis process.

Because of the involvement of university educators who are professional artists and designers, and others who are intrigued by learning from and through the arts, design, and digital technologies, TES project activities have been enhanced by "collective creativity" (Samaras et al., 2008). The rich multiplicity of developmental activities in workshops and meetings over the years has only been possible because of the contributions of those who have used their professional and academic expertise to co-facilitate these activities (Pithouse-Morgan \& Samaras, 2018). Through collective exploration, community participants have developed and enacted arts- and design-informed self-study research methods, including drawing (Van Laren et al., 2014), poetry and video footage of poetic performances (Chisanga, Rawlinson, Madi, \& Sotshangane, 2014; PithouseMorgan et al., 2015), play scripts and dramaturgical analysis (Meskin, Van Der Walt, Scott, De Beer, \& Pithouse-Morgan, 2017), and vignettes (Hiralaal, Matebane, \& Pithouse-Morgan, 2018). In this academic work, community members have collaborated in using artistic forms of expression "to represent and reinterpret, construct and deconstruct meaning, and communicate" (Samaras, 2011, p. 100).

In many respects, the TES workshops have offered training and development in specific arts-informed research methods and pedagogic practices. Many of the participants have completed their graduate degrees using these methods and some are still in the process. Many who were not published at all before have had publications as a result of participating in this project and collaborating with others using arts-informed research practices.

Building on this groundwork that had been done over the years, we liaised with community members to design a collective arts-informed analysis process. We came up with a three-phase process. The first phase involved using collage and poetry as collaborative arts-informed modes of analysis with TES participants. The second phase involved us as community leaders composing research poems to evoke and communicate our individual understandings of the participants' 
analyses. In the third phase, each leader responded to an interpretive poem. Our emphasis in designing this process was not on creating collages and poems that would demonstrate artistic or literary merit; rather, the intention was to offer TES participants and leaders outlets to look through creative analytical lenses (Richardson \& St. Pierre, 2005) to generate evocative and meaningful insights.

\section{Phase One: Creating Collage and Poetry with TES Participants}

To begin the analysis process, we invited all TES participants to submit detailed email responses to four questions:

1. How has your participation in the self-study research community so far been of value/not of value to you?

2. What challenges/successes are you currently experiencing as a selfstudy supervisor?

3. What challenges/successes are you currently experiencing as a selfstudy researcher?

4. What suggestions do you have for future self-study research community activities?

Twenty-two written submissions were received. A student assistant collated the responses. Next, we arranged a workshop to which we invited everybody to come and be part of an arts-informed analysis process. The workshop focused on using collage and poetry to work with the written responses that had been received prior to the workshop.

Thereafter, 31 TES community participants, inclusive of the four leaders, attended the 2-day arts-informed self-study research workshop. Participants were randomly divided into four groups. Each group focused on one of the abovementioned four questions. The groups were provided with the collated, anonymous responses to the selected question.

Three members of our leadership team (Theresa, Thenjiwe, and Delysia) each joined different groups, while Kathleen moved from group to group, observing and taking photographs. Our purpose in joining the groups was not to provide direction for the groups; rather, it was to experience firsthand and contribute to the creative analysis process.

Within a 90-minute period, each group created a collage representing the collated responses. The collage-making involved creating a multifaceted visual image by pasting images and text found in magazines onto a large piece of white chart paper. As Butler-Kisber (2008) explained, in qualitative inquiry "collage can mediate understanding in new and interesting ways for both the creator and the viewer because of its partial, embodied, multivocal, and nonlinear representational potential" (p. 265). 
The group activity of creating a collage was followed by another 90 -minute slot for collage transcription, using guidelines adapted from the work of Van Schalkwyk (2010). Collage transcription involved the numbering of main images and creation of a transcript with a brief description of each consecutively numbered main image, including reasons for selecting it and the associated thoughts, feelings, and meanings.

Owing to the specific guidelines and limited time given for each of the activities, fun and enthusiasm were increased as the participants engaged and made decisions quickly to create their collages and transcripts. Figures 1 and 2 offer examples of a collage and accompanying transcript. Upon reporting on the outcome of their activity, the group of participants who produced the pictorial collage (Figure 1) indicated that it is an expression and acknowledgment of lived experiences within the TES community as a "picture of overlapping, messy, and non-linear activities."

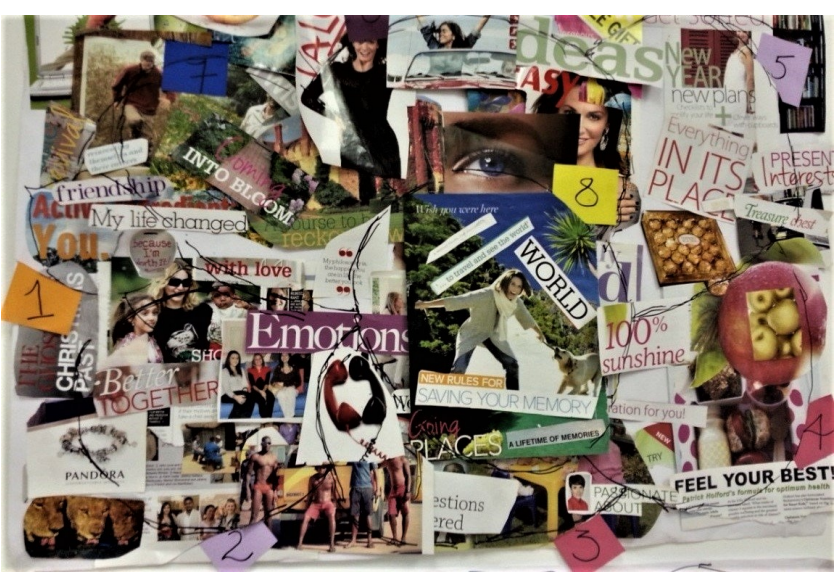

Figure 1. Group A's collage. (This represented responses to the question: "How has your participation in the self-study research community so far been of value/not of value to you?")

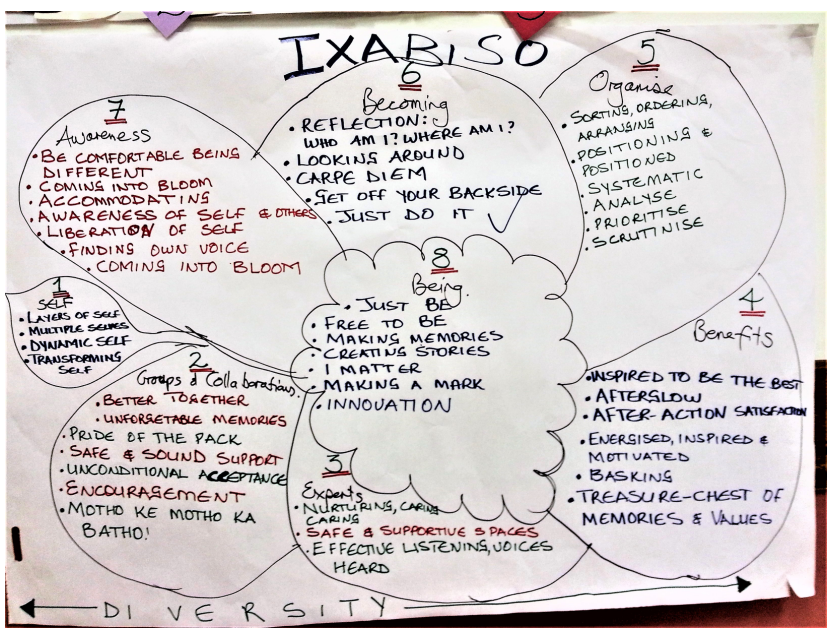


Figure 2. Group A's collage transcript. Ixabiso is an isiXhosa noun, meaning "value or worth."

The completed collages and collage transcripts were displayed on the walls for viewing and discussion by all participants.

The second day of the workshop introduced the idea of composing research poems using the French Malaysian pantoum poem format, which comprises a sequence of "repetitive lines [that allow] for the repetition of salient or emotionally evocative themes" (Furman, Lietz, \& Langer, 2006, p. 28). We did not intend to limit individual or group creativity by specifying the poetry format, but rather to provide fuel to ignite a creative adventure. Because of prior experience in facilitating poetic inquiry with large groups (Chisanga et al., 2014; PithouseMorgan et al. 2016b), we were aware of the challenges inherent in the task of collectively composing a poem within a limited time. Hence, we did not suggest to the groups that they should take the time to consider other poetic genres.

Research poetry is "a method of turning research interviews, transcripts, observations, personal experience, and reflections into poems or poetic forms" (Faulkner, 2007, p. 219). In our experience, both novice and experienced academics can feel unsure about this unconventional method when it is unfamiliar to them (Chisanga et al., 2014; Pithouse-Morgan et al., 2014; Pithouse-Morgan et al., 2016b). Nonetheless, through a supportive and collaborative process, participants indicated that they experienced collective accomplishment and joy in composing poems, without the constraining fear of individual failure.

Within a 90-minute slot, each group selected from their collage transcript interesting or significant words and phrases to create a found poem (Butler-Kisber, 2002 ) in the pantoum format. Through spirited discussions, each group composed a found poem that was displayed on a poster (for example, Figure 3 ). 


\section{Ixabiso}

Be comfortable being, just be Glowing, basking, dynamic me Who am I? Different \& diverse

Better together, pride of the pack

Glowing, basking, dynamic me Come into bloom

Better together, pride of the pack Creating stories, a chest of treasures

Come into bloom

Who am I? Different \& diverse Creating stories, a chest of treasures

Be comfortable being, just be -Just Be-

Figure 3. Group A's pantoum poem: "Ixabiso"

Together, the four poems created by the groups could be viewed as a "poetry cluster..., a powerful way of expressing a subtle range of nuances about a topic while simultaneously producing a more general overview" (Butler-Kisber \& Stewart, 2009, p. 4). Each group then performed its poem in its own way and interacted with animated audience responses as a means of enriching the community's creative analytical practice. The expression of the energy in the poems through performance brought to life the meaning of the words on pages of text (Whitehead, 2009).

After the poetic performances, we held a concluding 90-minute plenary discussion, with all participants, on the substance and performances of the poems, as well as the creative analytical activities of collage and poetry. Participants drew attention to the emergent nature and concrete and multilayered characteristics of the creative analytical activities. Participants also highlighted the power of bringing creativity and the visual into research. Furthermore, the conversation signaled the usefulness of bringing together multiple perspectives and insights through collaborative analysis. This principle is best demonstrated in the benefits of collective learning as expressed in the words shown in the pantoum poem, "Ixabiso" (Figure 3).

There was a strong feeling of the energizing value of joy and playfulness in the collaborative arts-informed process. Many felt that this could also inspire dynamic ways to approach learning, teaching, and research in universities, especially with students who often struggle to follow and understand concepts taught in an additional language (English) or who may be visual learners, as observed by several participants: 
It's a very powerful way of actually learning in a creative way-how to handle data, how to manage data and how to analyse it. For me, it was a very powerful visual image of demonstrating analysis, which can be scary and mind-boggling if you try to read about it. For visual learners like myself, it's a wonderful feeling. (Sagie)

I also think we must never underestimate the teaching that we're doing. We are teaching each other. That's really important. And it's quite a natural way to learn as opposed to reading. (Lee)

One of the things l'd take away with me would be research made fun. It's liberating! (Lazarus).

The whole process was very emergent and messy; a lot of the decisions were made on the fly, but slightly guided. There was a very slender thread that held it all together. And, I think at times it was almost like we wanted more order but then abandoned ourselves to the process and, lo and behold, something manifested! (Chris)

\section{Phase Two: Composing Research Poems as TES Leaders}

The next phase of the inquiry involved us, as the TES leaders, composing research poems to evoke and communicate our individual understandings of the participants' analysis as represented in the four pantoum poems. Kathleen initiated this poetry writing process in her capacity as team leader and as a researcher who has frequently used poetry as an individual and collective creative activity (Pithouse-Morgan, 2016; Pithouse-Morgan et al., 2014; Pithouse-Morgan et al., 2017). She hoped to prompt creative analytical engagement with the pantoums by eliciting multiple representations using the traditional Japanese renga and tanka poetry formats (Poets.org, 2004a, 2004b). The renga is a form of linked-verse poetry, customarily created by two or more poets as a kind of conversation (Poets.org, 2004a) and the tanka is a more concise poetic form, having only one stanza of five lines (Poets.org, 2004b). Tankas were historically written as personal messages between two people (Breckenridge \& Clark, 2017). Because the renga and the tanka are both originally dialogical poetic forms, Kathleen saw them as apt conduits to articulate our learning in dialogue with each other and the pantoums composed by TES participants. However, in her view, the experience of poetic inquiry process itself would be more important than producing conventionally precise renga or tanka poems.

Each of us individually composed a renga of four stanzas, with each stanza representing one of the pantoums created by community participants. Next, each of us created one tanka from her own renga, using only words and phrases already contained within the renga. Kathleen anticipated that by using the concise tanka 
format we would be able to further condense the learning expressed in our multiverse renga poems (Furman \& Dill, 2015).

After having worked independently, Theresa, Thenjiwe, and Delysia then emailed their poems to Kathleen, who collated the eight poems into two poetry clusters of renga (Figure 4) and tanka (Figure 5). These clusters helped to elucidate our individual interpretations, and they revealed resonances across our readings of the participants' poems.

In the emails that accompanied the rengas and tankas, Theresa, Thenjiwe, and Delysia expressed their responses to the act of poetry making:

For once, I don't care what anyone thinks, I have had so much fun doing this! Really enjoyed the process. The tanka was much more challenging, I thought. (Theresa)

Thank you for fun time that you created for me! I have engaged with writing poems in my doctoral thesis but never used this kind of poetry writing process before. (Delysia)

I am very glad I had to do this work on my own. In the past, I relied on colleagues who are more familiar with poetry and its nuances; I just followed along. It was very humbling, as it exposed my poetic vulnerabilities. I had genuine fearful moments. Key lesson from the exercise: I shall be more patient and understanding with my graduate students who battle to write or understand what I regard and have taken for granted as the basics of writing 
and conducting research. I look forward to further personal discovery. I appreciate that playing and scholarship can coexist. (Thenjiwe)

Figure 4. The renga poetry cluster based on four pantoums produced by participants.

\section{Theresa's Renga \\ Who am I? Just me, \\ A chest of treasures diverse. \\ Glowing, basking me. \\ Rigour! Is it trustworthy? \\ Limited time, large workload. \\ Tears release tension. \\ Joint journey to knowing self. \\ Collaboration! \\ Connecting the dots I am. \\ Discovery! I know I am! \\ Delysia's Renga \\ Different Just be \\ Who am I? Dynamic me \\ Better together \\ Risk taking with critical friends \\ Limited time and large workload \\ Journey to knowing \\ Fruit of collaboration \\ Creativity \\ Getting to know who I am Voyage of discovery}

\section{Thenjiwe's Renga}

A comfortable being I am

Dynamic me basks into gloom

Creating different dynamic glowing stories

Effective mentorship gets joys with taking risks

Rigour is taking risks with self-study

Knowing creativity in joint collaboration

Journey of knowing releases tears of tension

Creative joint journey in collaboration

Discovering, getting, connecting, solidifying our bold base

The voyage of light bulb getting bigger

\section{Kathleen's Renga}

Better together

Different and dynamic

A chest of treasures

Trustworthy critical friends

Questioning and risk-taking

Collaboration

Joint journey to knowing self

Creativity

Bold steps of discovery

Our voyage of connecting
Theresa's Tanka

Large workload! Time, tears!

Who am I? A diverse self.

Joint journey to self?

Connecting dots, discovery!

Basking me, glowing I am!

Thenjiwe's Tanka

Getting bigger

Joint journey

Connecting

Dynamic journey

Voyage of light
Delysia's Tanka

Journey to knowing

Who am I? dynamic me

Creativity

Risk taking with critical friends

Voyage of discovery

Kathleen's Tanka

A chest of treasures

Trustworthy critical friends

Creativity!

Bold steps of discovery

Our voyage of connecting

Figure 5 . The tanka poetry cluster.

\section{Phase Three: Creating and Responding to an Interpretive Poem}


For the final phase of our collaborative arts-informed self-study research process, Kathleen composed a free-verse interpretive poem (Figure 6) based on the most frequently used words in the tanka poem cluster: journey, voyage, discovery, connecting, friends, critical, self, dynamic, creativity, joint. The purpose was to create a composite poem to elicit our subjective responses as researchers and leaders of the TES community (Langer \& Furman, 2004).

\begin{tabular}{|l|}
\hline Journey \\
Critical voyage \\
Joint creativity \\
Dynamic discovery \\
Connecting self, friends \\
\hline
\end{tabular}

Figure 6. The interpretive poem: "Journey."

Kathleen shared the interpretive poem and, over the next few months, we each wrote several reflective responses to the poem. Kathleen collated these responses and looked across them for connecting threads. Through these solo activities, we were challenged to engage in the introspection that we, as project leaders and research supervisors, solicit from our community members and graduate students. The resultant responses revealed three connecting elements of our learning from and about our multicultural educational research community. What follows is a joint answer to our guiding question: "What pedagogic implications for educational research capacity development can be drawn from a collective analysis of TES project experiences?"

1. An enabling environment with people who are concerned and who care is critical to bringing to life the full potential of the community:

Meeting regularly and forming strong bonds for academic support has opened my eyes to something I would never have thought possible. There was support and genuine cooperation with a community that encouraged and reminded me constantly that my role was critical and mattered. This way, I was more productive and my job more meaningful. (Theresa)

The journey happens with others, who are friends. So, it is a safe journey. For me the word critical means that it is life giving or life takingI believe more the former if we journey together and the latter if we journey alone. (Delysia)

Being kept joined to one another is what the "Journey" poem mostly relays to me. In so doing, each person enriches and contributes to the collective journey. It is in remaining connected to friends that life is sustained and renewed. (Thenjiwe) 
The poem brings into focus our purpose in facilitating a multicultural research community in a higher education environment that still suffers from the anger and pain of the oppressive and divisive education systems of the past. In this milieu, our work towards putting into practice a collective, optimistic reimagining of South African higher education takes on a special urgency. (Kathleen)

2. Listening to and accommodating fellow participants' points of view are essential community values:

As the South African higher education sector experiences a painful transition, partners within the sector could take a leaf from our multicultural research community values; in particular, that of the importance of learning together, and of equally reflecting on and being conscious of the values of co-learning. Co-learning requires participants to listen to each other and accommodate various points of view of how each participant perceives learning to have occurred. (Thenjiwe)

It has been a very effective demonstration of reflexive ubuntu, a philosophy so desperately needed in this country and especially in our higher education institutions, which are literally burning even as I write this. A little bit of talking and listening, a little bit of a shared space and experience can reassure everybody that we are all on the same side and can recreate a better future working together. (Theresa)

Witnessing others' growth and learning from and with them is restorative. (Kathleen)

Every participant's story has significant value. These stories are doors to new knowledge. I see us as a multicultural community that has come together and celebrated our commonality of improving our practice from what it was to something new that is inclusive of the ideas and concepts of others in the group. As we work and interact together over a period of time we are able to be co-creators of knowledge through caring and listening. Through our regular interactions and time spent together, as we tell our stories and engage in getting to know each other in a caring and listening manner, we share ourselves as resources for each other. It is during and through the sharing process that we undergo transformation. We co-learn. We change. Doors are opened and we venture into new areas. (Delysia)

3. There is educational value in providing opportunities for creativity to be set free through participation in the community:

I, as many of our students do, come from an educational background where the arts and poetry have not been given much educational value compared to chemistry, mathematics, science, and technology. I was not provided with learning opportunities to express my creativity through performance and fun activities in the classroom. In and through my participation in the project, I had fun and felt that I was heard and seen. 
I have learned the importance of providing opportunities to explore areas where we are not necessarily comfortable to go, because it is there where our true creativity is unleashed. I am a novice researcher and a person who comes strongly from a chemistry and positivist approach embracing objectivity and generalisability in research. However, through co-learning and engaging in the poetic process and self-study research, I am now moving towards flourishing in my practice as a teacher and researcher. (Delysia)

Our community's joint creativity is a discovery that is contained in the "Journey" poem. Our co-learning has been fun, as demonstrated in our creative activities; it has been an indication that research and fun need not be mutually exclusive. (Thenjiwe)

The community has enabled me to be creative in my teaching, to do innovative research and learn new ways of handling challenging situations in my work life. It has been wonderful to see the endless possibilities for doing research right there in the space that had previously felt tight and uncomfortable, and which seemed to be throttling the research capacity in me. The campus based TES groups, for instance at my university, have not only seen this grow, but novice researchers are doing conference presentations and publishing, using arts-based research methods and methodologies. They all acknowledge being empowered by this process (evidence of these is there in the many collaborative papers that have come out over the years as publications). (Theresa)

The "Journey" poem makes visible the potency of collaborative creativity through integrating the arts into our research and teaching. That has been one of the greatest gifts of working in this transdisciplinary, multiinstitutional project. It is because of our dynamic, creative collaboration that we keep learning and discovering. (Kathleen)

\section{Flourishing Together Through Caring, Listening, and Creativity}

Whereas there has been a relatively slow pace of transformation in the South African public higher education sector, the Transformative Education/al Studies (TES) project has, since 2011, managed to put in place collaboration, colearning, and arts-informed, fun-filled activities to foster the growth of a multicultural educational research community of participants. Self-study research is the main pillar from which the TES project draws its intellectual imagination, focusing on strategies of improving educational practices in the interest of the common good. Reflecting collaboratively on our research activities sits at the core of our purpose. The focus on transformed and improved outcomes ensures that all our endeavors are geared towards positive development of the TES project community participants and their practice, while not disregarding the many 
tensions and troubles that permeate our higher education landscape. The transformation path of the TES project is firmly entrenched in the pursuit of an environment that is enabling and sensitive to the multicultural characteristics and diverse contexts of its participants. Building enabling and empathetic relationships across the multiplicity of all participants has been possible because we have all come to understand that this is a safe environment, based on the concept of reflexive ubuntu and what has been referred to by others as "caring research" (Uusiautti \& Maatta, 2016). These are spaces where participants "share the passion and enthusiasm to influence positively and collaborate" with a common cause and where research is manifested "in the relationship between researchers...and their mutual open and respectful interaction" (Uusiautti \& Maatta, 2016, p. vii).

In our contemporary South African public higher education context, the damages and divides of the apartheid past weigh heavily. Indeed, in our contemporary global public higher education context, such damages and divides often seem to be proliferating rather than diminishing. In the face of what can appear to be dishearteningly insurmountable social and educational challenges, our long-term investment in collaborative creativity and reflexive ubuntu has allowed us to see and perform in imaginative and responsive ways that can enrich our individual and collective practice. The growth of this South African community has also demonstrated that where there is a common purpose for humanity and where the human spirit is paramount, differences in terms of racial, cultural, religious, or other backgrounds can become shared resources for co-learning, rather than locked doors that divide us.

Our journey has been a methodological and educational voyage, but, critically, it has also been an ethical inquiry that stems from and generates compassion for self and others. Through collective, arts-informed analysis, we as the TES leaders have heard and seen the multiple perspectives of community participants and expressed our own learning in dialogue with theirs, finding resonances and insights. A dynamic discovery of how we can grow through reconnecting in arts-informed ways with critical friends brings about an optimistic awareness that change for the better is always possible. Witnessing others' growth and learning from and with them is healing when we nurture each other and say, "Let's hold hands and move together." Building a multicultural research community that brings to life shared qualities of caring, listening, and creativity can help us to flourish together in putting into practice a socially just reimagining of public higher education.

\section{Notes}

1. This is based on isiZulu, the most widely-spoken South African indigenous home language. 
2. isiXhosa is one of the South African indigenous languages, mostly spoken in Eastern Cape province.

3. In South Africa, every master's or doctoral student is usually assigned one suitably qualified and experienced academic advisor, known as a "supervisor."

\section{Acknowledgment}

We are thankful for the unique contributions of all the TES community participants and would like especially to highlight the contributions of all those who assisted with and joined in the arts-informed analysis workshop. In particular, we thank Sagie Naicker, Lee Scott, Lazarus Mulenga, and Chris de Beer for kind permission to include their comments in this article.

In preparation for the TES project, we acquired ethical clearance from each of the three host universities. Additionally, all staff-students who registered for selfstudy research applied for individual ethical clearance in accordance with the regulations of the university in question. In line with the undertakings that we have made at each institution in order to obtain ethical clearance, the information, images, and names included in this article have been used with the explicit consent of all involved.

We gratefully acknowledge support and grant funding for TES project activities from the National Research Foundation of South Africa (Education Research in South Africa Grant Numbers 74007 and 90380 and Incentive Funding for Rated Researchers Grant Number 90832). We further acknowledge that any opinion, findings, conclusions, or recommendations expressed in this material are those of the authors, and therefore the funders do not accept any liability in regard thereto.

\section{References}

Academy of Science of South Africa. (2010). The PhD Study: An evidence-based study on how to meet the demands for high-level skills in an emerging economy. Pretoria, South Africa: Author.

Breckenridge, J. P., \& Clark, M. T. (2017). Two to Tanka: Poetry as a duoethnographic method for exploring sensitive topics. Journal of Research in Nursing, 22(6-7), 451-462.

Butler-Kisber, L. (2002). Artful portrayals in qualitative inquiry: The road to found poetry and beyond. Alberta Journal of Educational Research, 48(3), 229239.

Butler-Kisber, L. (2008). Collage as inquiry. In J. G. Knowles \& A. L. Cole (Eds.), Handbook of the arts in qualitative research (pp. 265-276). Thousand Oaks, CA: Sage. 
Butler-Kisber, L., \& Stewart, M. (2009). The use of poetry clusters in poetic inquiry. In M. Prendergast, C. Leggo, \& P. Sameshima (Eds.), Poetic inquiry: Vibrant voices in the social sciences (pp. 3-12). Rotterdam, Netherlands: Sense.

Cariaga-Lo, L., Dawkins, P. W., Enger, R., Schotter, A., \& Spence, C. (2010). Supporting the development of the professoriate. Peer Review, 12(3), 1922.

Carper, B. (1978). Fundamental patterns of knowing in nursing. Advances in Nursing Science, 1(1), 13-24.

Chisanga, T., Rawlinson, W., Madi, S., \& Sotshangane, N. (2014). Enacting reflexivity through poetic inquiry. Educational Research for Social Change, $3(2), 21-36$.

Clark, N. L., \& Worger, W. H. (2016). South Africa: The rise and fall of apartheid (3rd ed.). Abingdon, UK: Routledge.

Conle, C. (2004). Special series on multiculturalism in curriculum inquiry. Texts, tensions, subtexts, and implied agendas: My quest for cultural pluralism in a decade of writing. Curriculum Inquiry, 34(2), 139-167.

Davids, N., \& Waghid, Y. (2016, October 10). \#FeesMustFall: History of South African student protests reflects inequality's grip. Mail \& Guardian. Retrieved from http://mg.co.za/article/2016-10-10-feesmustfall-history-ofsouth-african-student-protests-reflects-inequalitys-grip

Davis, C. L. (2017). Working in corners, spaces, bends and turns: How transdisciplinary approaches and attitudes might challenge and shape the practices of educational developers and early career academics. In P. Gibbs (Ed.), Transdisciplinary higher education (pp. 137-152). Cham, Switzerland: Springer.

Du Pré, R. (2010). Universities of technology in the context of the South Africa higher education landscape. In R. Townsend (Ed.), Kagisano No. 7: Universities of Technology-Deepening the Debate (pp.1-41). Pretoria, South Africa: South African Council on Higher Education.

Faulkner, S. L. (2007). Concern with craft: Using ars poetica as criteria for reading research poetry. Qualitative Inquiry, 13(2), 218-234.

Furman, R., \& Dill, L. (2015). Extreme data reduction: The case for the research tanka. Journal of Poetry Therapy, 28(1), 43-52.

Furman, R., Lietz, C. A., \& Langer, C. L. (2006). The research poem in international social work: Innovations in qualitative methodology. International Journal of Qualitative Methods, 5(3), 24-34.

Haarhoff, D. (1998). The writer's voice: A workbook for writers in Africa. Halfway House, South Africa: Zebra Press.

Harrison, L., Pithouse-Morgan, K., Conolly, J., \& Meyiwa, T. (2012). Learning from the first year of the Transformative Education/al Studies (TES) project. 
Alternation, 19(2), 12-37. Retrieved from http://alternation.ukzn.ac.za/Files/ docs $/ 19.2 / 02 \% 20$ Har.pdf

Hiralaal, A., Matebane, R., \& Pithouse-Morgan, K. (2018). Learning through enacting arts-informed self-study research with critical friends. In J. K. Ritter, M. Lunenberg, K. Pithouse-Morgan, A. P. Samaras, \& E. Vanassche (Eds.), Teaching, learning, and enacting of self-study methodology: Unraveling a complex interplay (pp. 295-312). Singapore: Springer Nature.

LaBoskey, V. K. (2004). The methodology of self-study and its theoretical underpinnings. In J. J. Loughran, M. L. Hamilton, V. K. LaBoskey, \& T. Russell (Eds.), International handbook of self-study of teaching and teacher education practices (Vol. 2, pp. 817-869). Dordrecht, Netherlands: Kluwer.

Langer, C., \& Furman, R. (2004). Exploring identity and assimilation: Research and interpretive poems. Forum: Qualitative Sozialforschung [Forum: Qualitative Social Research], 5(2), Article 5. Retrieved from http://www.qualitative-research.net/index.php/fqs/article/view/609

Loveless, D., Sturm, D., Guo, C., Tanaka, K., Zha, S., \& Berkley, E. E. (2013). Cross-disciplinary collaboration to engage diverse researchers. New Forums Press, 27(2), 11-18.

Meskin, T., Van Der Walt, T., Scott, L., De Beer, C., \& Pithouse-Morgan, K. (2017). Shoes, suitcases, stones: Creative engagement with ourselves as artistresearcher-teachers through object inquiry. In D. Pillay, K. PithouseMorgan, \& I. Naicker (Eds.), Object medleys: Interpretive possibilities for educational research (pp. 175-196). Rotterdam, Netherlands: Sense.

Meyiwa, T., Chisanga, T., Mokhele, P., Sotshangane, N., \& Makhanya, S. (2014). Complex journeys and methodological responses to engaging in self-study in a rural comprehensive university. Perspectives in Education, 32(2), 102116.

Mitchell, C., \& Weber, S. (2005). Just who do we think we are...and how do we know this? Re-visioning pedagogical spaces for studying our teaching selves. In C. Mitchell, S. Weber, \& K. O'Reilly-Scanlon (Eds.), Just who do we think we are? Methodologies for autobiography and self-study in teaching (pp. 1-9). London, UK: RoutledgeFalmer.

Mitchell, C., \& Pithouse-Morgan, K. (2014). Expanding the memory catalogue: Southern African women's contributions to memory-work writing as a feminist research methodology. Agenda, 28(1), 92-103.

Molinsky, A. (2007). Cross-cultural code-switching: The psychological challenges of adapting behaviour in foreign cultural interactions. Academy of Management Review, 32(2), 622-640.

Nkomo, M. O. (Ed.). (1990). Pedagogy of domination: Toward a democratic education in South Africa. Trenton, NJ: Africa World Press.

Pithouse-Morgan, K. (2016). Finding my self in a new place: Exploring professional learning through found poetry. Teacher Learning and Professional 
Development, 1(1), 1-18. Retrieved from http://journals.sfu.ca/tlpd/ index.php/tlpd/article/view/1

Pithouse-Morgan, K., Coia, L., Taylor, M., \& Samaras, A. P. (2016a). Exploring methodological inventiveness through collective artful self-study research. LEARNing Landscapes, 9(2), 443-460. Retrieved from http://www.learninglandscapes.ca/images/documents/ll-no18/pmorgan.pdf

Pithouse-Morgan, K., Naicker, I., Chikoko, V., Pillay, D., Morojele, P., \& Hlao, T. (2014). Entering an ambiguous space: Evoking polyvocality in educational research through collective poetic inquiry. Perspectives in Education, 32(4), 149-170.

Pithouse-Morgan, K., Naicker, I., Pillay, D., Masinga, L., \& Hlao, T. (2016b). 'Sink or swim?': Learning from stories of becoming academics within a transforming university terrain. South African Journal of Higher Education, $30(1), 1-20$.

Pithouse-Morgan, K., Morojele, P., Pillay, D., Naicker, I., Chikoko, V., Ramkelawan, R., \& Rajpal, R. (2012). "The air is hostile..." Learning from an African international postgraduate student's stories of fear and isolation within a South African university campus. Alternation, 19(2), 73-93.

Pithouse-Morgan, K., Muthukrishna, N., Pillay, D., Van Laren, L., Chisanga, T., Meyiwa, T., Moletsane, R., Naicker, I., Singh, L., \& Stuart, J. (2015). Learning about co-flexivity in a transdisciplinary self-study research supervision community. In K. Pithouse-Morgan \& A. P. Samaras (Eds.), Polyvocal professional learning through self-study research (pp. 145-171). Rotterdam, Netherlands: Sense.

Pithouse-Morgan, K., Pillay, D., \& Naicker, I. (2017). "Knowing what it is like": Dialoguing with multiculturalism and equity through collective poetic autoethnographic inquiry. International Journal of Multicultural Education, 19(1), 125-143. Retrieved from http://ijme-journal.org/index.php /ijme/article/view/1255/1167

Pithouse-Morgan, K., \& Samaras, A. P. (2018). "Many stories matter": Taking a polyvocal stance in learning about teaching of self-study. In J. K. Ritter, M. Lunenberg, K. Pithouse-Morgan, A. P. Samaras, \& E. Vanassche (Eds.), Teaching, learning, and enacting of self-study methodology: Unraveling a complex interplay (pp. 313-328). Singapore: Springer Nature.

Poets.org. (2004a). Poetic form: Renga. Retrieved from https://www.poets.org/ poetsorg/text/poetic-form-renga

Poets.org. (2004b). Poetic form: Tanka. Retrieved from https://www.poets.org/ poetsorg/text/tanka-poetic-form

Richardson, L., \& St. Pierre, E. A. (2005). Writing: A method of inquiry. In N. K. Denzin \& Y. S. Lincoln (Eds.), The Sage handbook of qualitative research (3rd ed., pp. 959-978). Thousand Oaks, CA: Sage. 
Roth, W., \& Tobin, K. (2004). Co-generative dialoguing and metaloguing: Reflexivity of processes and genres. Forum: Qualitative Social Research, 5(3), Art. 7. Retrieved from http://nbn-resolving.de/urn:nbn:de:0114fqs040370

Samaras, A. P. (2011). Self-study teacher research: Improving your practice through collaborative inquiry. Thousand Oaks, CA: Sage.

Samaras, A. P., Adams-Legge, M., Breslin, D., Mittapalli, K., O’Looney, J., \& Wilcox, D. (2008). Collective creativity: A learning community of self-study scholars. In A. P. Samaras, A. Freese, C. Kosnik, \& C. Beck (Eds.), Learning communities in practice (pp.133-147). Dordrecht, Netherlands: Springer.

Samaras, A. P., Hicks, M. A., \& Berger, J. G. (2004). Self-study through personal history. In J. J. Loughran, M. L. Hamilton, V. K. LaBoskey, \& T. Russell (Eds.), International handbook of self-study of teaching and teacher education practices (Vol. 2, pp. 905-942). Dordrecht, Netherlands: Kluwer.

Samaras, A. P., Karczmarczyk, D., Smith, L., Woodville, L., Harmon, L., Nasser, I., . . S Swanson, R. (2014). The shark in the vitrine: Experiencing our practice from the inside out with transdisciplinary lenses. Journal of Transformative Education, 12(14), 368-388.

Schuck, S., \& Russell, T. (2005). Self-study, critical friendship, and the complexities of teacher education. Studying Teacher Education, 1(2), 107121.

Soudien, C., Michaels, W., Mthembi-Mahanyele, S., Nkomo, M., Nyanda, G., Nyoka, N., Seepe, S., Shisana, O., \& Villa-Vicencio, C. (2008). Report of the Ministerial Committee on Transformation and Social Cohesion and the Elimination of Discrimination in Public Higher Education Institutions. Pretoria, South Africa: Government Press.

South African Council on Higher Education. (2007). Review of higher education in South Africa. Pretoria, South Africa: Author.

South African Council on Higher Education. (2014). Framework for institutional quality enhancement in the second period of quality assurance. Pretoria, South Africa: Author.

South African Department of Education. (1997). Education white paper 3: A programme for the transformation of higher education. Pretoria, South Africa: Government Press.

South African Human Rights Commission. (2016) Transformation at public universities in South Africa. Pretoria, South Africa: Author.

South African National Planning Commission. (2012). National Development Plan 2030: Our future-make it work. Pretoria, South Africa: Government Press.

Timm, D. (2016). From exclusion through inclusion to being in my element: Becoming a higher education teacher across the apartheid-democratic 
interface. In D. Pillay, I. Naicker, \& K. Pithouse-Morgan (Eds.), Academic autoethnographies: Inside teaching in higher education (pp. 95-115). Rotterdam, Netherlands: Sense.

Uusiautti, S., \& Maatta K. (2016). The basis of caring research. Rotterdam, Netherlands: Sense.

Van Laren, L., Pithouse-Morgan, K., Chisanga, T., Harrison, L., Meyiwa, T., Muthukrishna, N., Naicker, I., \& Singh, L. (2014). 'Walking our talk': Exploring supervision of postgraduate self-study research through metaphor drawing. South African Journal of Higher Education, 28(2), 639659.

Van Schalkwyk, G. J. (2010). Collage life story elicitation technique: A representational technique for scaffolding autobiographical memories. The Qualitative Report, 15(3), 675-695.

Whitehead, J. (2009). Using a living theory methodology in improving practice and generating educational knowledge in living theories. Educational Journal of Living Theories, 1(1), 103-126.

Wisker, G., Robinson, G., \& Shacham, M. (2007). Postgraduate research success: Communities of practice involving cohorts, guardian supervisors and online communities. Innovations in Education and Teaching International, 44(3), 301-320.

\section{Author Contact}

Kathleen Pithouse-Morgan: pithousemorgan@ukzn.ac.za

School of Education, University of KwaZulu-Natal, Edgewood Campus, Ashwood, South Africa

Theresa Chisanga: tchisanga@wsu.ac.za

Department of Arts, Walter Sisulu-University, Mthatha Campus, Mthatha, South Africa

Thenjiwe Meyiwa: meyiwt@unisa.ac.za

Office of the Vice-Principal: Research, Postgraduate Studies, Innovation and Commercialisation, University of South Africa, Muckleneuk Campus, Pretoria, South Africa

Delysia Norelle Timm: timmdn@dut.ac.za

Office of the DVC Academic, Durban University of Technology, Steve Biko

Campus, Durban, South Africa 